\title{
KRONIK
}

\section{Yeni Türk Ceza Kanunu'nun Hazırlanış Süreci}

Devrim Aydın, A.Ü. Siyasal Bilgiler Fakültesi Araştırma Görevlisi

Halen yürürlükte bulunan 1 Mart 1926 ve 765 sayılı TCK, İtalyan Ceza Kanunu esas alınarak sınırlı bazı değişikliklerle hazırlanmıştı. Kanunun yaklaşık 80 yıllık uygulaması sonucunda ülkemizde belli bir doktrin ve içtihat oluşturulmuş olmasına rağmen kanunun belli maddelerinin düzeltilmesi, dilinin sadeleştirilmesi, hayatın ve çağın gerektirdiği yeni düzenlemelerin kanuna eklenmesi haklı olarak gündeme getirilmişti. Bu nedenle ilki 1940'ta olmak üzere 1950, 1987, 1989 ve 1997'de öntasarılar hazırlanmıs fakat bunlar kanunlaşma imkanı bulamamışlardı 1997 öntasarısının gözden geçirilmesi ile 2000 yılında 498 maddelik yeni bir öntasan daha hazırlanmıştı. 1987, 1989, 1997 ve 2000 yıllarında hazırlanan tüm bu tasarılar Prof. Dr. Sulhi Dönmezer başkanlığında oluşturulan komisyonlar tarafından hazırlandığından "Dönmezer Tasarısı" olarak da adlandırılmaktaydılar. Bütün bu tasarılar akademik çevreler, barolar, üniversiteler ve kamuoyu tarafından tartışılma imkanı bulmuş fakat eksiklikleri, hukuk çevrelerinde kabul görmemesi ve kanun koyucunun istekli olmaması gibi değişik nedenlerle kanunlaşmamıştı.

Seçimlerin ardından 2000 öntasansı "Hükümet Tasanıs”" olarak 12. 05. 2003 'te Başbakan Erdoğan tarafından TBMM Başkanlığı'na sevk edildi. 2003 yılındaki bu Hükümet Tasarısı bazı değişikliklerle 2000 yılında hazırlanan öntasarının aynısıydı. Hükümet Tasarısı olarak TMMM Başkanhığı'na sunulan metnin, 21. 10. 2003 tarihinden 12. 05. 2004 tarihine kadar geçen 7 aylık sürede "Adalet Alt Komisyonu" çalışmaları sonunda 348 maddeye indirilmesi daha önceki öntasarıları hazırlayanlan ve bu öntasarılan destekleyenleri de şaşırtmıştı. Başta Ankara ve İstanbul Baroları ile üniversitelerin hukuk fakültelerinin düzenledikleri toplantılarda bu tasarnnn "yetersiz, hatalı, aceleye getirilmiş" hükümler içerdiği, 7 aylık bir sürede ceza kanunu gibi temel bir kanunun hazırlanamayacağı, kamuoyunda bu tasanının yeterince tartışılmadığı, uygulamada sıkıntılar doğuracağı şeklinde eleştiriler yöneltilmiş ve bu haliyle kanunlaşmaması gerektiği ileri sürülmüştü. Ankara ve İstanbul'da yapılan toplantılarda tartışmalarda hazır bulunan alt komisyon üyeleri tasarıya getirilen eleştirileri dikkate alarak bunlan değiştireceklerini ve bu eleştiriler doğrultusunda yapılacak düzenlemelerle tasarının TMMM Genel Kurulu'na 
sunulacağını ifade etmişlerdi. Fakat bu sürede gündeme "zina" tartışması yön verince, tasarıya getirilen hiçbir eleştiri dikkate alınmadan tasarı kamuoyuna açıklandıktan 4 ay sonra kanunlaştı.

Belli hukuki kavramların kullanılması gereken tartışmalar yapılmalıyken bu yapılmadı ve zina tarışması gölgesinde kalan TCK tasarısının eleştirilen ve belki kanun koyucunun da fark ettiği maddelerinin düzeltilebilme imkanı ortadan kalktı. Türkiye' de TCK tartışması zina tartışmasına indirgenince olaya $A B$ de taraf oldu ve $A B$ organları ve yetkililerinin açıklamaları "zinasız bir ceza kanunu" olarak ifade cdildi. Elbette yürürlükteki kanunda olmayan ve çağdaş ceza hukuklarında bulunmayan zina fiilinin suç olmaması gerekiyordu ama ceza kanunu tasarısı da zaten zina suçunu getirmemişti. Ama eleştiriler karşısında bizzat Başbakanın zinanın suç olması ve bunun kadınlar lehine olduğu, zinanın şikayete bağlı bir suç olmasını tercih ettiği açıklamalanı gelince TCK tasarnsı bir yana bırakılıp zina tartışması yapıldı. "Bu tasan zinasız çıksın!" diyenlerle "Bu tasarı zinayı da içersin!" diyenler basında yer bulurken, "Bu tasarı çıkmasın!" diyenler reyting yapamadı. Türkiye'de "zina" tartışması tüm hızıyla sürerken tartışmalara $A B$ de müdahil olmuş ve haklı olarak ceza kanunuyla değil, kanunda zina suçunun yer alıp almayacağı ile ilgilenmeye ve tüm kanunu bu olasılık çerçevesinde değerlendirmeye başlamıştı. Tasarının tartışıldığı günlerde düzenlenen bir panelde konuşan AB Konseyi Temsilcisi S. Tellenbach kanuna yöneltilen eleştiriler hakkında "Önce çıkarın sonra duizelir." diyerek AB organlarının da bu işe ciddiyetsizce yaklaştığını ortaya koymaktayd. Henüz Avrupa için ortak bir ceza hukundan söz edilemezken, (Kuşkusuz modern ceza hukuku ilkelerine, insan hakları kriterlerine ve evrensel normlara uygun kanunların yapılması gerekirken) AB'nin Türk Ceza Kanunu'na bu kadar müdahil olması ve üstelik hiçbir bilimsel ve hukuksal kaygı taşımadan, kanunu okuyup anlayamadan olumlamaları Türk kamuoyunda kanunun tartışılmadan kabullenilmesini sağladı. Anadili Türkçe olan ceza hukuku profesörleri bile bu kanunun dilinin ve hükümlerinin anlaşılmaz olduğundan şikayet ederken $\mathrm{AB}$ yetkililerinin bu kanunu göklere çıkarmalarının nedenlerini araştırmak ceza hukukunun değil ama bir başka disiplinin işidir.

Tasarı üzerinde iktidar partisi AKP ve ana muhalefet partisi CHP'nin "uzlaştıkları" vurgulanarak tasarının 14 Eylül 2004'te TBMM Genel Kurulu'na sunulacăğ hükümet tarafindan dile getirildiğinde artık tartışılan Ceza Kanunu Tasarısı değil "zina”ydı. Zina tartışması sürerken AKP ve CHP'nin zinanın suç olması konusunda uzlaştıkları ve Tasarı'ya zina suçunun ekleneceği haberleri 
basında yer almaya başladı. ${ }^{2}$ Kamuoyundan ve $A B$ yetkililerinden kimsenin beklemediği bir tepki gelince $\mathrm{CHP}$ yetkilileri zinanın suç olması yönünde bir uzlaşmanın söz konusu olmadığını duyurdular. ${ }^{3} 3$ Eylül tarihli gazetelerde Başbakan Erdoğan'ın "Bu (zinanın suç olarak düzenlenmesi), insanlık onurunu kurtaracak ve kadın erkek eşitliğini sağlayacak bir adımdır." demesi ve suçun §̧ikayete bağlı ve 1995 öncesi dönemden farklı olarak cezai yaptınmın kadın ve erkek için aynı olacağı şeklindeki açıklamaları ${ }^{4} 14$ Eylül'de Genel Kurul'a gelen Tasannın zina suçunu da içereceği yolundaki şüpheleri iyice artırmıştı. 14 Eylül'de Genel Kurul'da görüşülmeye başlanan Tasarı maddeleri hızla kabul edilmesine rağmen, 16 Eylül'de yürürlük ve yürütme maddeleri geri çekilerek Tasanını, Ceza İnfaz Kanunu ve Ceza Muhakemeleri Usulü Kanunu ile beraber çıkarılacağı ifade edildi. Buna rağmen artık Tasarının "zina suçu"nun dahil edilmek istenmesinden ötürü kanunlaşmadığı şüphesi artmıştı. AB'nin Genişlemeden Sorumlu Komiseri G. Verheugen ve AP Dışilişkiler Komisyonu Başkanı Brok, zina suçunun çağdışı olduğunu, üyelik sürecinde Türkiye'nin yeni bir ceza kanunu hazırlamasını dahası Tasan'nın kanunlaşmasını, tasarının tüm maddelerinin kabul edilip de yürürlük ve yürütmeye dair son iki maddesinin kabul edilmemesinin anlaşılmaz olduğunu, müzakerelere başlanması yönünde tavsiyede bulunulması için TCK'nın çıkarılması gerektiğini dile getirince 5 , iç kamuoyunda da tasarının biran evvel kanunlaşması yüksek sesle ifade edildi. Verheugen ve danışmanlarımın açıklamalanna yanıt veren Başbakan Erdoğan, "Arkadaşlar biz Türkiyeliyiz, Türküz. Kendi kararımızı kendimiz vereceğiz. AB ile ilgili birileri bizi bir yere şartlandırmasın. AB ile ilgili, Kopenhag siyasi kriterleri ile ilgili ne varsa hepsini yerine getirdik."6 şeklindeki açıklaması Türkiye'de "ilerleme raporu" merakla beklenirken olayın siyasi krize dönüşmesine neden oldu. Başbakan Erdoğan'ın "Bu meseleye AB karışamaz." "7 şeklindeki ifadesine rağmen Verheugen'in Sözcuisü Filori "Yeni TCK Kopenhag Kriterlerinin olmazsa olmaz parçası ve müzakereler için mihenk taşıdır. Tasarı ilerleme raporunun açıklanacağı güne kadar kanunlaşmahıdır."8 diyerek AB'nin kesin tavrımı bildirince Tasarı'nın yürürlük ve yürütme maddeleri 26. 09. 2004'te kabul

231 Ağustos 2004 tarihli Radikal ve 1 Eylül 2004 tarihli Cumhuriyet Gazetesi.

32 Eylül 2004 tarihli Radikal Gazetesi.

43 Eylül 2004 tarihli Radikal, Cumhuriyet ve Milliyet Gazeteleri.

510 Eylül 2004 tarihli Cumhuriyet ve 19. eylül.2004 tarihli Radikal Gazetesi.

6 18. Eylül 2004 tarihli Radikal Gazetesi.

718 Eylül 2004 tarihli Radikal Gazetesi.

818 Eylül 2004 tarihli Radikal ve Milliyet Gazetesi. 
edildi. Cumhurbaşkanı'nın 5237 sayılı Türk Ceza Kanunu'nu 11. 10. 2004'te onaylamasıyla Yeni TCK 25611 sayılı ve 12. 10. 2004 günlü Resmi Gazete'de yayımlanarak kanunlaşt1.

\section{Yeni Türk Ceza Kanununun Sistemi ve Niteliği}

Kanunun yürürlük maddesini düzenleyen 344. maddesine göre Kanunun "İmar kirliliğine neden olma" başlıklı 184. maddesi kanunun yayım tarihinde, "Çevrenin kasten kirletilmesi" başlıklı 181. maddenin 1. fıkrası ile "Çevrenin taksirle kirletilmesi" başhılı 182. maddesinin 1. fikrası kanunun yayımı tarihinden iki yll sonra, diğer hükümleri ise 1 Nisan 2005'te yürürlüğe girecektir. Anamuhalefet Partisi CHP, m.181/1 ve m.182/1 hükümlerinin kanunun yayımından iki yıl sonra yürürlüğe girmesini düzenleyen 344 . maddesinin iptali için Anayasa Mahkemesi'nde dava açtı. Bu iptal davası gündemdeyken yeni TCK'nın bazı suçların cezalanı azaltması nedeniyle "Sanığın lehine olan hüküm uygulanır." ilkesi gözetilerek halen cezaevinde bulunan ve haklannda "kesin hüküm" verilmiş olan kişilerin cezalannın yeniden hesaplanarak tahliye edilip edilmeyeceği tartışılmaya başlandı. Ceza hukukunda, yeni hüküm eskisine oranla daha az ceza öngörmekteyse lehe olan hüküm kuralına dayanılarak daha az cezayı gerektiren hüküm uygulanır; fakat burada verilmiş "kesin hüküm" varken lehe olan yeni kanun uygulanabilecek miydi? Öte yandan yayımlanmış fakat henüz yürürlüğe girmemiş olan bir kanun söz konusuydu. Bu konuyu düzenleyen 5252 sayılı TCK'nın Yürürlük ve Uygulama Şekli Hakkında Kanun, 04.11.2004'te kabul edildi. 5252 sayılı Kanun'un 9. ve 10. maddelerinde "lehe olan hükümlerin" nasıl uygulanacağı meselesine açıklık getirilmiş oldu.

Ceza kanunları belli bir felsefi temele, belli bir kültürel ve bilimsel birikime dayanarak hazırlanan "code" niteliğindeki temel kanunlardandır. 1926 tarihli Türk Ceza Kanunu'nun esasını oluşturan 1889 tarihli (Zanardelli) İtalyan Ceza Kanunu Klasik Okul'un etkisiyle ve bu okulun başlıca temsilcileri tarafindan hazırlanmışken, 1930 tarihli (Rocco) İtalyan Ceza Kanunu Teknik Hukuk Okulu'nun etkisini taşımaktadır ve Faşist dönemim izlerini taşıyan bu kanunun bazı hükümleri 1936'da Türk Ceza Kanunu'na alınmıştır. ${ }^{9}$ Yeni TCK'nın ceza

9 Bazı gazete haberlerinde ve bazı köşe yazılarında geçen "80 yıllık faşist ceza kanunu", "Mussolini İtalyası'ndan alınan 78 yıllık TCK tarihe karıştı." ya da "Faşist Italyan Ceza Kanunu" ifadeleri Avrupa ve dahası Türkiye tarihi hakkındaki bilgi eksikliğinin ifadesi olmalıdır Ceza Kanunumuz 1926'da İalya'dan alındığında yürürlukte olan 1889 tarihli Zanardelli Kanunu dur ve Mussolini iktidarının izlerini taşıyan 1930 tarihli Rocco Kanunu henüz yoktur. Kaldı ki İtalya’da faşizmin 
hukuku okullanndan hangisine dayandı $\breve{g}_{1}$ anlaşılmamaktadır. Kanunun dayandığı belli bir okulun olmaması bu kanunun hangi felsefi, kültürel birikime dayandırıldığını anlamayı olanaksız kılmaktadır. Öte yandan kanunun hazırlanışında İtalya, Almanya, İspanya, Rusya ceza kanunları ile Türk Ceza Kanunu hükümlerinden değişik hükümler alınmak suretiyle karma bir ceza kanunu sistemi oluşturulmuş, bunun sonucunda da kanunun içinde birbiriyle çelişen hükümler ve sistem bozukluklan ortaya çıkmıştır. Kanunda sadece cürümlere yer verilmiş, kabahatler ceza kanununda düzenlenmemiştir. ${ }^{10} \mathrm{Bu}$ doğrultuda kanun genel hükümler ve özel hükümler (suç tipleri) olmak üzere iki kitaptan ve toplam 345 maddeden oluşmaktadır.

Genel Hükümler başlıklı birinci kitap 3 kısma ayrılarak bu kitapta temel ilkeler, tanımlar, kanunun uygulama alanı, ceza sorumluluğunun esası ve yaptırımlar düzenlenmiştir. Birinci kitaptaki yeniliklerden biri, önce cezai sorumluluğun esaslarını sonra da yaptırımlan düzenlemesidir. Aynca "tanım" maddesine (m. 6) yer verilerek kanundaki bazı ifadelerin tanımlanması yoluna gidilmiştir. Kanunun ikinci kitabında ise suçlar düzenlenmiştir. Suç tiplerinin yer aldığı ikinci kitap dört kısma ayrılmıştır. Burada en önemli yenilik, "uluslararası suçlar" başlıklı birinci kısımda; soykırım, insanlığa karşı suçlar, göçmen kaçakçıllı̆ı ve insan ticareti suçlanna yer verilmesidir. Bu kitabın bir başka yeniliği ise "millete ve deviete karşı işlenen suçlar"a kanunun son kısmında yer

ardından ceza kanunundaki baskıcı hükümler ayıklanmış, $A B$ üyelik süreci ile de kanunun sistemi korunarak değişiklikler yapılmışıı. Ayrıca, 1908'de Ceza Kanunname - i Humayun'un yerine yeni bir ceza kanunu yapmak amaciyla Adliye Nazirı Necmettin Molla Bey, Yusuf Ziya Özer'e 1889 tarihli İtalyan Ceza Kanunu'nu Fransızca'dan tercüme ettirmiş, bu çalışma 1925 yılında yeni bir ceza kanunu yapmak için Mahmut Esat Bozkurt tarafından görevlendirilen "Eskişehir Komisyonu"nun çalışmalarına temel oluşturmuştur. 1889 tarihli (Zanardelli) İtalyan Ceza Kanunu durup dururken keşfedilmemiştir.

10 Suçlar, cürüm ve kabahattir. Sadece "suç" terimi kullanilırsa bu ifade, cürüm ve kabahati kapsar. Cürümlerin kabahatlere oranla daha ciddi suçlar olduğu ve bu nedenle daha ağı ceza ile cezalandırılması gerektiği savunulmuştur. Öte yandan ceza adaletinin daha hızlı işleyebilmesi, mahkemelerin iş yükünün azaltılması, ağır ihlâllerin (cürümlerin) daha etkin takip edilebilmesi için daha hafif nitelikteki ihlâllerin suç olmaktan çıkarılması yoluna gidilmektedir. Bazen de suç olan fiillerin cezalarının azalıılması, hürriyeti bağlayıcı cezaların (hapis) yerine para cezalarının uygulanması söz konusu olmaktadır. Tüm bu faaliyetler "depenalizasyon" olarak adlandırılmaktadır. Kanun koyucunun Yeni TCK'da kabahatlere yer vermemiş olması geniş ölçüde bir depenalizasyona gidileceği şeklinde yorumlanmış fakat henüz resmi bir açıklama yapılmamışır. 
vermesi ve kişilere karşı işlenen suçları daha önce düzenlemesidir. Kanun koyucu bu yola giderek ceza kanunumuzun devleti öne çıkardığı, bireyleri geri plana atarken devleti öncelikle ve önemle koruduğu yolundaki eleştirileri dikkate almıştır. Devlete karşı işlenen suçlar kanunun son kısmında düzenlenmiş fakat mevcut kanunumuza göre bu suçların cezası ciddi biçimde artınlmıştır. Bu da göstermektedir ki bir kanunda hükümlerin düzenlenme sırası ile korunan hukuki değerin bire bir ilgisi yoktur ve hükümlerin düzenleniş sırası ile verilen ceza arasında orantı olmaz. Yeni TCK bazı suçların cezasını azaltmakla beraber birçok suçun cezasını büyük oranda artırmıştır. Öte yandan kanunda suçun basın yoluyla işlenmesi, yaklaşık 20 yerde suçun ağırlatıcı nedeni olarak düzenlenmiştir.

İkinci kitapta suç tipleri düzenlenirken cürümlerin tasnifi bakımından benimsenen kriter konusunda yer yer tereddütlere düşülmüş, yürürlükteki ceza kanunumuzda olduğu gibi "suçun hukuki konusu kriteri" uygulanmış ama hatalar da yapılmıştır. Yine, daha önce kabahat niteliğindeki suçların cürüm olarak düzenlenmesi hem bu fiillere verilen cezaları artırmış hem de sistemi bozmuştur. Örneğin "genel tehlike yaratan suçlar" başlığı altında m. 172'de "radyasyon yayma", m. 173'te "atom enerjisi ile patlamaya sebebiyet verme", m. 174'te "patlayıcı, yanıcı, zehirleyici maddelerin izinsiz el değiştirmesi", m. 175 'te "akıl hastası üzerindeki bakım ve gözetim yükümlülügünün ihlali”, $m$. 176 'da inşaat ve yıkımla ilgili emniyet kurallarına uymama", m. 177'de ise hayvanın tehlike yaratabilecek şekilde serbest bırakılması" düzenlenmiştir. Bu maddeler alt alta siralaninca kanun koyucu atom bombası atan ya da radyasyon yayan kişi ile hayvanını başıboş bırakan kişinin fiilinin ihlal ettiği hukuki konunun aynı nitelikte olduğunu, bu fiilleri işleyen faillerin "tehlikeliliğini" birbirine yakın görmüş olmalı ki bunların tümünü aynı başlık alında düzenlemiş. Aslında kanun koyucu mevcut ceza kanunumuzda kabahat olan bazı filleri Yeni Ceza Kanunu'nda cürüm olarak düzenlemiş ve böyle bir mantık hatasına da neden olmuştur. Oysa depenalizasyon iddiasında olan bir ceza kanununda hayvanı başıboş bırakmak, akıl hastası üzerindeki gözetim yükümlülüğün ihlali gibi fiillerin "cürüm" olarak düzenlenmemesi gerekirdi.

Bu kanunda çok sayıda yazım ve noktalama yanlışının yanı sıra yinelemelere ve aynı anlama gelen kelimelere yer verilerek dil bilgisi hatalan yapılmışır. Kanun koyucunun dil ve yazım kuralları konusunda daha özenli davranması gerekirdi. Ceza kanununda bir bağlacın ya da bir virgülün yeri, bir tamlama ya da yüklemin ifade edilişi kişilerin özgürlüklerini zedeleyebilir. Örneğin, m. 196'nın kenar başhğg "usulsüz ölü gömülmesi" değil, "ölünün usulsüz gömülmesi" olmalıydı; m. 184'teki "imar kirliliği”, m. 107'deki "şantaj” ifadeleri Türkçe açısından doğru değildir; m. 21/2'de "rağmen" denilmişken m. 22/3'te "karşın" denilmiştir, kanun koyucu kullanacağ 1 kelime konusunda bir 
karar vermeliydi. 6. maddenin (c) bendinde "... süreli veya geçici olarak..." ve m. 213'teki "... korku ve panik yaratmak ... " ifadeleri aymı anlama gelen kelimelerin tekrarıdır. Buna bir örnek de m. 28'de geçen "cebir ve şiddet" ifadesidir. Cebir; şiddet ve tehditi içerir. Şiddet maddi, tehdit ise manevi cebirdir. Yine, m. 131/2'de “... suç ölmüş olan kişinin hatırasına karşı işlenmiş olursa ..." denilmektedir. Ölümle kişilik son bulduğuna göre "ölünün hatırasına karşı işlenmiş olursa” denilmeliydi. M. 181 ve 182 'de geçen “... atık veya artıklan toprağa, suya veya havaya kasten veren kişi ... " ifadesinde "veren" yerine "bırakan" denilmesi daha doğru olurdu. M. 86'nın kenar baslı̆̆ı "Kasten yaralama" olmamalıydı, çünkü "yaralama” ifadesi, maddedeki “...başkasının vücuduna acı veren....algılama yeteneğinin bozulması..." ifadelerini karşılamaz. 765 sayılı TCK'da olduğu gibi "müeessir fiil" ya da "etkili eylem" denilmesi daha doğru olurdu.

Kanunda soykırım, insanlığa karşı suçlar, göçmen kaçakçılığı, insan üzerinde deney, organ ve doku ticareti gibi yeni suç tiplerine yer verilmesi ve birçok düzenlemenin de daha sade bir dille ifade edilmesi kanunun olumlu yanlarındandır. Yine, m. 73/8 ile ceza hukuku sistemimize "uzlaşma" kurumu getirilmesi de ciddi bir değişikliktir. "Suçtan zarar gören ile failin şikayete bağlı suçlarda doğan zaran kısmen veya tamamen giderilmesi veya ödenmesi konusunda uzlaşıtıklarında bu hususun $C$. Savcısı veya hakim tarafından saptanması halinde kamu davasının açılmayacağı veya davanın düşürüleceğine karar verileceği" ifade edilmiştir. "Uzlaşma" kurumunun beklenen yararı sağlayıp sağlayamayacağı ve özellikle usul ekonomisi yönünden ceza mahkemelerindeki dava sayısını azaltıp azaltmayacağı uygulamada görülecektir. Burada, bu yazının niteliğini de dikkate alarak ve genel olarak çokça eleştirilen maddeleri kısaca sıralamaya çalışacağız.

M. 1- "Ceza kanununun amacı" başlıklı bu hüküm, 1997 tarihli Rusya Federasyonu Ceza Kanunu'nun 2. maddesinde yer almaktadır. SSCB Ceza Kanunu'nun 1. maddesinde SSCB Ceza Kanunu'nun amacinın proletarya diktatörlügünü ve sosyalist devleti korumak olduğu belirtilmekteydi. Rusya'da yaşananların ardından yeni bir ceza kanunu yapilırken 80 yıllık uygulamaya paralel biçimde ceza kanununun amacına yer verilmiştir. Böyle bir maddeye ceza kanunu içinde, hele böyle bir uygulaması hiç olmayan TCK'da gerek yoktu. Eğer ceza kanunu temel bir kanun olduğu için kanunun amacı yazıldıysa o halde temel bir kanun olan Türk Medeni Kanunu'na da kanunun amacı konulmalıydı. Kaldı ki hiçbir kanunda o kanunun amacı yazmaz çünkü kanunların amaçlan onlanı içeriklerinden anlaşılır. Bildirmeli, yaptırımsız önerme niteliğindeki bu hüküm, ceza kanunu uygulayıcısının işine de yaramayacaktır. Kanunun gerekçesinde de bu maddenin neden konulduğu belirtilmemiştir. Bu maddenin ifade ediliş şekli de çok eleştiriye uğramıştır. 
If ade biçimi itibariyle Yeni Ceza Kanunu'nun sadece cezalandırıcı ve devleti koruyucu niteliği vurgulanmıştır; oysa modern ceza kanunlarının bir amacı da toplumu daha ileriye götürebilmektir. Öte yandan maddede geçen "kamu düzen ve güvenliğini korumak" ifadesi yine aynı maddedeki "toplum barışını korumak"la aynı anlama geldiğinden, gereksiz bir yinelemedir. Maddede "Ceza kanununun amacı ... suç işlenmesini önlemektir." ifadesi yanlıştır, zira suç işlenmesini önlemek ceza kanununun amacı değil işlevidir. Ceza kanununun amacı suçluların cezalandırılmasıdır. Ceza kanununun varlığı, suç işlenmesini önlemez. Bugün herhangi bir çağdaş ülke ceza kanununda hele hiçbir Avrupa ülkesinde böyle bir hüküm yoktur, çünkü ceza kanunlan işlevsiz hüküm içermemelidir.

M. 2 - "Suçta ve cezada kanunilik ilkesi" kenar başlıklı bu maddede suç ve cezanın ancak kanunla konulabileceği şeklindeki kurala yer verilmiştir. Bu maddede de gerek yokken bu ilkenin kanunun tekelciliği, kanunun açık ve kesin olması, kanunun geçmişe uygulanmazlığı ilkelerinden sadece "kanunun tekelciliği" ilkesi (idarenin düzenleyici işlemleriyle suç ve ceza koyamayacağı ve kıyas yasağı) ifade edilmiş fakat bu yapılırken ciddi yanlışlar yapılmıştır. Kanun koyucu "suç ve cezada kanunilik" ilkesini benimsediğini ifade ettikten sonra bir ders kitabında bulunması gereken açıklamalan burada yapmamalıydı. Fakat burada kanunilik ilkesinin ne olduğu sıralandığına göre "kanunun açık, anlaşılır olması gerektiği" kuralı da sayılmalıydı. "Kanunun geçmişe uygulanmazlığ" ilkesi ise daha sonra 7. maddede "zaman bakımından uygulama" kenar başlığı altında düzenlenmiştir. Maddedeki kıyas yapılamayacağına dair "Kanunların suç ve ceza içeren hükümlerinin uygulanmasında kıyas yapılamaz." ifade hatalıdır. Çoğul ifade kullanıldığına göre kıyas yasağı ceza kanunu dışındaki başka kanunları da kapsar mı, kapsarsa bunlar hangileridir? Yine, "Kanunların suç ve ceza içeren hükümlerinin uygulanmasında kuyas yapılamaz." ifadesi gereksizdir zira kıyas yasağı zaten suç ve cezanın ancak kanunla konulacağı demek olduğuna göre bunu açıklamaya gerek yoktur. Çünkü kanun normu koyar ama bunu kanunda açıklamaz. Bu tür açıklamalar kanunda değil caza hukuku kitabında olur. Maddenin son cümlesinde geçen "Suç ve ceza içeren hükümler kıyasa yol açacak biçimde geniş yorumlanamaz." ifadesi hatalıdır, çünkü hukukta yorum ve kıyas bir birinden tamamen farklı iki zihinsel faaliyettir. Hukukçunun işi yorum yapmaktır, genişletici yorum da bir yorum (maddi açıdan yorum) türü olup kiyasla ilgisi yoktur.

M. 3 - "Adalet ve kanun önünde eşitlik" kenar başlıklı bu madde de Rus Ceza Kanunu m. 6'nın ifadesine benzemektedir. Maddede geçen "adalet" nedir belli değildir. Adalet önünde eşitlik olmaz, ancak kanun önünde eşitlik ilkesinin hayata geçirilmesi, yani eşitliğin sağlanması adaleti sağlar. Maddede "Suç 
işleyen kişi hakkında işlenen fiilin ağırlığıyla orantılı ceza ve güvenlik tedbirine hükmolunur." ifadesi bu kanunun iddia edildiği gibi çağdaş olmadığının en temel göstergesidir. Modern ceza hukukunda ceza ve güvenlik tedbirleri işlenen fiilin ağırlığına göre değil, failin kişiliğine (tehlikeliliğine) göre belirlenir. Bu ifade bu kanunun çağdaş ceza hukukunun geldiği noktadan uzakta olduğunun göstergesidir. Kanunun kenar başlığı ile madde arasında da bir ilgi yoktur. Maddenin birinci fıkrası cezanın tayininin neye göre yapılacağını bclirtirken (Bu hüküm m. 6l'de, "Cezanın belirlenmesi" başlığı altında yer almalıydı.) ikinci fıkrada aynmollık yasağı ifade edilmiştir. İkinci fikra ifadesinin de burada değil, Anayasa'da yer alması daha isabetli olurdu. Ayrıca ikinci fıkradaki "ayrımcılık yasağı" ile madde kenar başlığındaki "kanun önünde eşitlik" ayrı şeylerdir. Kaldı ki kanunun 122. maddesinde ayrımcılık yapmak bir suç olarak düzenlendiğine göre burada gereksiz bir tekrar vardır. İkinci fıkrada geçen "Ceza kanununun uygulamasında kişiler arasında ... milliyet ... felsefi inanç, milli veya sosyal köken, doğum ...yönünden ayrım yapılamaz ..." ifadesi hatalıdır. Buradaki "felsefi inanç" ifadesi (1961 ve 1982 Anayasası'ndan kaynaklanan bir hatadır.) yanlıştır. Felsefi inanç olmaz, felsefi kanaat olur. İnançların felsefesi olur (Hristiyan felsefesi, İslam felsefesi gibi) ama felsefenin inancı (Hegelci inanç, Platoncu inanç gibi) olmaz. Yine aynı fıkrada önce "milliyet" sonra da "milli veya sosyal köken" denmiştir. Bunlar aynı anlama gelmez mi ? Aynı anlama geliyorlarsa neden aynı cümlede tekrar edildi? Aynı anlama gelmiyorsa neden tanımlar maddesinde ne olduğu belirtilmedi? "Doğum yönünden ayrım" ne demektir; bu ifade doğum yerini mi, doğum biçimini mi, doğuştan getirilen özellikleri mi, doğum zaman ve tarihini mi belirtmektedir? Buradaki belirsiz ve hatalı ifadeler "kanunun açıklığı ilkesi" yani "kanunilik ilkesi" ile çelişmez mi? Kanunlar, hele ceza kanunları kulağa hoş gelen her ifadeyi içermemelidir, aksi halde uygulamada sorunlara neden olur.

M.4- "Kanunu bilmemek mazeret sayılmaz." ilkesini yumuşatmak gerektiği savunulmaktaydı. Fakat burada bu ilke yumuşatılmaya çalışılırken "Sakınamayacağı bir hata nedeniyle kanunu bilmediği için meşru sanarak bir suç işleyen kimse cezaen sorumlu olmaz." ifadesi uygulamada tartışmaya neden olacaktır. "Sakınamayacağı bir hata" ifadesi, hatanın belirlenmesi için yeterli değildir ve "meşru sanarak" ifadesi de belirsizdir.

M. 5 - Maddede geçen "Bu kanunun genel hükümleri özcl ceza kanunları ve ceza içeren diğer kanunlardaki suçlar hakkında da uygulanır." ifadesi doğru değildir. "Ceza içeren kanunlardaki suçlar" belirsiz ve yanhı̧ bir ifadedir. Ifade doğru olsa bile bu kanunun genel hükümlerinin ceza içeren diğer kanunlardaki suçlara uygulanabilirken, ceza ve güvenlik tedbirlerine de uygulanmamasının gerekçesi nedir? Aynca Yeni TCK'nın sadece "genel hükümlerinin" özel ceza 
kanunlarına uygulanmasına olanak tanıması uygulamada sıkıntılara neden olacaktır. Örneğin Askeri Ceza Kanunu uygulamasında "hırsızhlk suçu"nun ya da Basın Kanunu'nda "hakaret suçu”nun belirlenmesinde Yeni TCK'nın özel hükümlerine başvurulamayacak mıdır? Oysa, yürürlükteki 765 sayılı TCK m. 10 'daki "Bu kanundaki hükümler, hususi ceza kanunlarının buna muhalif olmayan mevaddı hakkında da tatbik olunur." diyen ifadesi dilinin sadeleştirilmesiyle korunabilirdi. Bu madde özel kanunlarla ilişkiyi belirlediğine göre sistematik olarak "temel ilkeler ve tanımlar" bölümünde değil de "kanunun uygulama alanı" adlı ikinci bölümde düzenlenmesi daha doğru olurdu.

M. 6 - "Tanımlar" kenar başlıklı bu madde kanundaki belirsiz ifadeler dikkate alındığında daha geniş olmalıydı. Maddenin (b) bendinde "vatandaş" deyiminden "fiili işlediği sırada Türk vatandaşı olan kişi anlaşılır" denmiş̧ir. Oysa kanun koyucu taraf olduğumuz Suçlulann ladesine Dair Avrupa Sözleşmesi'nde iadesi talep edilen kişinin vatandaşlığında sonradan bir değişiklik olmuşsa iade anındaki vatandaşlığın esas alınacağını belirttiğini fark etmemiştir. Bu ifade Sözleşme'yle uyumsuzdur. Maddenin (d) bendinde "yargı görevi yapanlar" arasında savcı ve avukatlar da sayılmıştır. Bu hüküm uygulamada avukat ve savcıların da hakimler gibi sorumlu olmalanna neden olabilecek hatalı bir düzenlemedir. Savcı ve avukatlar "yargı görevi yapan" değil, ancak "adli görev yapan" kişi olabilir. Yargı görevi yapmak münhasıran yargıcın işidir. (j) bendinde geçen "Örgüt mensubu suçlu" ifadesi "örgüt mensubu kişi" olmahıydı. Çağdaş ceza hukukunda kesin hüküm yokken failin "suçlu" olarak nitelendirilmesi hukuk devleti ilkesine ve "suçsuzluk karinesi"ne aykırıdır.

M. 18 - Maddenin kenar başlığı hukuk tekniği açısından yanlıştır. "Geri verme" yerine "suçluları geri verme" denilmeliydi. Maddenin (b) bendinde geçen "düşünce suçu" ifadesinin ne olduğu belli değildir. Bu bentte geçen "siyasi suç" ifadesi zaten "düşüncesi nedeniyle suçlanan" kişiyi de kapsar. Yine "Iadede ihtisas ilkesini ifade eden" m.18/8 hükmü gereksizdir. Böyle bir ifade kanunda değil, ceza hukuku ders kitabında yer alır. Bu normun muhatabı kimdir? Kişiyi iade ettiğimiz ülkeye yükümlülük mü getirmekteyiz?

M. 20/2' de Tüzel kişiler hakkında ceza yaptırımı uygulanamayacağı ancak güvenlik tedbiri uygulanabileceğini düzenleyen bu hüküm, tüzel kişilerin suç faili olup olamayacakları ya da bünyelerine uygun ceza (örneğin kapatma ya da para cezası) verilip verilemeyeceği şeklindeki tartışma dikkate alındığında yetersizdir. Eğer tüzel kişilere ceza yaptırımı uygulanamayacaksa bunun Anayasa'da belirtilmesi gerekirdi. Öte yandan ancak hakkında ceza yaptırımı uygulanabilenlere güvenlik tedbiri şeklindeki yaptınmlar uygulanabileceğine 
göre, kanun koyucu bu hükmü getirirken yapurım teorisini görmezden gelmiştir.

M. 21'de "kast" ve "olası kast" tanımı yanlıştır ve uygulamada ciddi sıkıntılara neden olacaktır. Kastın varlığı için failin suç olan fiili bilerek ve (sonucu) isteyerek işlemiş olması gerekir. Maddede geçen "Kast, suçun kanuni tanımındaki unsurları bilerek ve istenerek gerçekleştirilmesidir." ifadesi ile kasun hiçbir ilgisi yoktur. Suçun kanuni tanımındaki unsurlar teknik bir mesele olup failden kanuni tanımdaki unsurları bilerek suç işlemesini beklemek için failin iyi bir ceza hukuku eğitimi almış olması gerekir. Ayrıca bu cümlede geçen "bilerek ve istenerek gerçekleştirilmesidir." ifadesi Türk dili açısından son derece yanlıştır, zira Türkçe'de etken ve edilgen iki fiil beraber kullanılmaz, "bilerek ve isteyerek ya da bilinerek ve istenerek" olmalıydı. M. $21 / 2$ 'deki "olası kast" tanımı da yanlıştır. Olası (muhtemel) kasıt, failin sonucu öngördüğu halde bu sonucun gerçekleşme ihtimalini göz önüne alarak ("Olursa olsun!" diyerek) hareketi yapmasıdır. Örneğin fail, pastanede oturan hasmını öldürmek için elindeki bombayı içeri attı̆ıında orada bulunan başka insanların da ölebileceği ihtimalini göz önüne alarak (Ölürlerse ölsünler!" diyerek) bombayı fırlatırsa, hasmı yönünden doğrudan kast, diğerleri yönünden ise "muhtemel/olası kast" vardır. Aynca maddenin gerekçesinde verilen örnekler de olası kasta değil, bilinçli taksire dair örneklerdir.

M. 22/2' de taksirin tanımı yanlı̧ yapılmışıı. Taksir; failin uyulması zorunlu davranış kurallarına uymak suretiyle önleyebileceği bir fiili bu kuralları ihlal ederek istemeyerek gerçekleştirmesidir. "Meslek ve sanatta acemilik" ile "emir ve talimatlara riayetsizlik" halleri taksir kahıbı olmaktan çıkarılmıştır. Sadece dikkat ve özen yükümlülüğüne aykırılık halleri taksir olarak düzenlenmiştir. Bu durumda "suç ve cezada kanunilik" ilkesi gereğince meslek ve sanatta acemi olan ya da emir ve talimatlara riayet etmeyen fakat gerekli bütün dikkat ve özeni gösteren kişinin cezalandırılıp cezalandırılmayacağı uygulamada tartışmalara yol açacaktır. M. 22/3'te bilinçli taksir tanımı eksiktir. Bilinçli taksir kişinin öngördüğu neticeyi istememesine rağmen neticeyi önleyebileceği kanaatiyle hareket etmesi halinde söz konusudur. Kasıt, olası kasıt, taksir ve bilinçli taksir tanımları teknik ayrımlar olup uygulamada bunların arasında faile verilecek ceza yönünden çok ciddi farklar vardır. Burada cezalar arasında ciddi farklar failin kusurundaki yoğunluk nedeniyle ortaya çıkmaktadır. Suçu, kusuru ve cezayı belirleyen normlar karmaşık, belirsiz ve hatalı ise kişi güvenliği nasıl sağlanabilecektir? Bu tanımlar arasında 5-10 yıllık mahkumiyet farkı olduğu göz önüne alınarak daha titiz bir çalışma yapılmalıydı.

M. 23'ün kenar başlığı "Neticesi sebebiyle ağırlaşmış suç" olmalıydı. Neticesi sebebiyle ağırlaşan suçta failin "kastettiğinden" daha ağır ya da başka sonuçlar meydana geldiğine göre kanun koyucunun bu netice bakımından "en azından 
taksirle" hareket edilmiş olmasını araması ciddi bir çelişkidir. Çünkü bizzat kanun koyucu davranışın "kasıtll" olmasını aramakta fakat sonuç yönünden "taksirli" olunmasını beklemektedir. Eğer fail kasıtlı davranmış da kastettiğinden daha ağır bir netice gerçekleşmişse aynı kişiden aýnı olayda taksirle davranmasını nasıl beklersiniz? Bir davranış ya kasıtlı işlenir ya da taksirli, bu yönde bir düzenleme hiçbir ceza kanununda yoktur. Bu hüküm m. $87 / 4$ ile de uyumsuzdur.

M. 24'ten madde 34'e kadar olan ikinci bölüm ise sistematik ve suç teorisi yönünden tamamen yanlıştır. Birbirinden tamamen farklı nitelikteki kurumlar "ceza sorumluluğunu kaldıran veya azaitan nedenler" başlığı alında bir arada sıralanmıştır. Kanun koyucu bilimsel ilerlemede doğru tasnifin önemli bir yer tuttuğunu bilmelidir. Bu kısımdaki kanunun hükmünü ve amirin emrini icra (m. 24), meşru savunma ve zorunluluk hali (m. 25), hakkın icrası ve mağdurun rızası (m. 26) fiilin hukuka aykırılığını ortadan kaldıran "hukuka uygunluk nedenleri /suçu ortadan kaldıran objektif nedenler"; cebir ve şiddet, korkutma ve tehdit (m. 28) ve hata (m. 30), "kusurluluğa etki eden neden"; haksız tahrik (m. 29) "suça etki eden neden"; yaş küçüklüği (m. 31), akıl hastalığı (m. 32), sağır ve dilsizlik (m. 33), alkol ve uyuşturucu madde etkisinde olma (m. 34) ise "isnat yeteneğini etkileyen neden"dir. Bunlann tümünün bir arada duizenlenmesi tutarlı değildir.

M. 25'te zorunluluk halinin tanımı yanlışur, zira tehlikenin ağırlığı ile konu ve kullanılan araç arasında orantı kurulamaz. Tehlike ile tehlikeden kurtulmak için yapılan hareket arasında orantı kurulabilir. Uygulamada sıkıntılar yaratacaktır.

M. 35 ve 36, "suça teşebbüs"le ilgilidir. 35. maddede geçen "doğrudan doğruya icraya başlama" ifadesi yanlıştır; teşebbüs kurumunda icraya dolaylı ya da doğrudan doğruya başlama gibi bir ayrım yoktur. Yine maddede geçen "işlemeyi kastettiği bir suçu elverişli hareketlerle ... icraya başlayıp ..." ifadesi yanlıştır. Teşebbüsün söz konusu olabilmesi için elverişli araçlarla icraya başlanması gerekir. M. 35'in ifadesi eksik teşebbüs aşamasına yer verilmediğini göstermektedir, oysa 36. maddede eksik teşebbüs aşamasında söz konusu olan gönüllü vazgeçmeye yer verilmiştir. M. 36/2'deki "Fail, suçun icra hareketlerinden gönüllü vazgeçer veya kendi çabalanyla suçun tamamlanmasınt veya neticenin gerçekleşmesini önlerse, teşebbüsten dolayı cezalandırılmaz; fakat tamam olan kısım esasen bir suç oluşturduğu takdirde, sadece o suça ait ceza ile cezalandırllır." ifadesi uygulamada çok tartışlacak ve ciddi adaletsizliklerin ortaya çıkmasına neden olacaktır. Fail, hasmını öldürmek kastıyla onu kurşun yağmuruna tutup sonra da hastaneye yetiştirip tedavi edilerek hayatta kalmasını sağlarsa artık adam öldürmeye teşebbüsten değil, adam yaralamaktan sorumlu tutulacaktır. Çünkü fail, burada tam da kanunun ifade ettiği gibi neticenin gerçekleşmesini yani mağdurun ölmesini 
engellemiştir; bu nedenle sadece tamam olan kısımdan yani mağdurun yaralanmis olmasından sorumlu olacaktır. Kanunun gerekçesinde "Tabancasındaki mermilerden sadece birini atıp mağduru yaraladıktan sonra engellenen fail, icra hareketleri bitmediği için adam öldürmeye "eksik teşebbüs"ten dolayı, buna karşılık silahındaki tek kurşunu atıp mağdura isabet ettiremeyen fail, icra hareketleri bittiği için "tam teşebbüs"ten dolayı cezalandırılmaktadır." ifadesi yanlıştır. Her iki örnekte de fail adam öldürmek için elverişli araç kullanıp icra hareketlerini tamamlamış fakat clinde olmayan nedenlerle kastettiği netice gerçekleşmemiştir. Burada her iki örnekte de "tam teşebbüs" söz konusudur. Maddenin gerekçesi kanunun ciddiyeti konusundaki şüpheleri artırmaktadır.

M.88'de geçen “...kişi üzerindeki etkisinin basit bir tıbbi müdahaleyle...” ifadesi açı değildir. 765 sayılı TCK'da günle ifade edilen etki daha tutarlıydı. "Basit tıbbi müdahale"nin ne olduğu belli olmadığından uygulamada sıkça bilirkişiye başvurulacak, bu durum da usul ekonomisi yönünden sakıncalara neden olacaktır.

M.96'da geçen "Bir kimsenin eziyet çekmesine yol açacak davranışlar" ifadesi tanımlanmahydı. "Eziyet" nedir, belli değildir. Uygulamada, siyasal ortama göre keyfi uygulamalara yol açabilecektir. Madde gerekçesinde yer alan "Bu fiiller, ani olarak değil, sistematik bir şekilde ve belli bir süreç içinde işlenmektedirler." ifadesi bu fiil ile daha önce düzenlenen işkence fiilleri arasındaki ayrımı iyice bulanıklaştırmaktadır. Çocuklanı resmi törenlerde bekletilmesi; bazı öğrencilerin üniversitelere alınmaması; belirlenen asgari ücretin/memur maaşının DİE'nin belirlediği asgari mutfak masrafından daha düşük olması ve bu nedenle asgari ücretlinin temel gida gereksinimini karşılayamaması; oruç tutan sporcunun antrenmana ya da maça çıkarılması; gıda yardımı dağıtımlarının gelişigüzel yapılması nedeniyle insanların birbirini ezmesi; vatandaşların muayene sırası, iş başvuru formu, vize almak ya da fatura yatırmak için hastane, kamu kurumu, elçilikler ve bankalarda saatlerce bekletilmesi fiillerinden hangisi "eziyet" suçunu meydana getirir?

M. 125'te "hakaret" kenar başh̆ğ altında hem hakaret hem de sövme suçu beraber düzenlenmiştir. Hakaret ve sövme iki ayrı suçtur; iki ayn suçun aynı cümlede düzenlenip aynı yaptırıma bağlanması ceza politikası açısından doğru değildir.

M. 147'de hırsızlık suçunda zaruret haline "hukuka uygunluk nedeni" olarak yer verilmiştir. Buna gerek yoktu çünkü zaten m.25/2'de zaruret hali düzenlenmiştir. Kanunun genel kısmında hukuka uygunluk nedeni düzenlendiğine göre, her suç için hukuka uygunluk nedenini tekrar etmek doğru değildir. 
M. 252/3'te "rüşvet" in tanımlanması yapılırken kullanılan ifade nedeniyle "basit rüşvet suçu" (Kamu görevlisinin yapması gerekeni yapması, yapmaması gerekeni yapmaması amacıyla vatandaşla anlaşarak yarar sağlaması) suç olmaktan çıkmıştır. Aksine uygulama "kanunilik ilkesi"ni ihlal edecektir. Yolsuzlukla mücadelede ciddi geri adım niteliğindeki bu düzenlemenin nedenini anlamak mümkün değildir ve gerekçede de bir açılama yoktur.

M. 278'deki "suçu bildirmeme" kenar başlıklı hüküm çağdaş ceza hukuku ve hukuk devleti ilkesine aykırıdır. "İşlenmekte olan bir suçu yetkili makamlara bildirmeyen kişi .. cezalandırtlır." ifadesi gerekçesinde de belirtildiği üzere işlenen bir suçtan haberli olan vatandaşlann bu durumu ilgili makamlara bildirmeleri yükümlülüğünü getirmiştir. Gerekçede elektrik hırsızlığı suçu işlendiğinin bilinip de bildirilmemesi örneği verilmiştir. Ama gündelik hayatta devletin ilgili makamlarının bildiği birçok suçu bildirmemek de bu düzenleme ile suç olmuştur. Örneğin otopark mafyası olarak tabir edilen kişilerin zorla para aldıklarını, komşunuzun çocuğunu veya eşini dövdüğünü, sokağınızda korsan kitap ve cd satıldığını, çocuklanın dilenciliğe zorlandığını bildirmemek bu hükümdeki suçu oluşturur. Kanun koyucu vatandaşlara anlaşılmaz bir yükümlülük getirmiştir. Uygulamada ya hiç uygulanmayacak ya da çok fazla sorun çıkaracak bir hükümdür.

M. 305'te "Temel milli yararlara karşı hareket" kenar başlıklı hüküm düşünce ve ifade hürriyetini sınırlandıncı biçimdedir. Temel milli yarann ne olduğu 305/4'te "bağımsızlık, toprak bütünlüğ̈̈, milli güvenlik ve Cumhuriyetin Anayasada belirtilen temel nitelikleri" denilerek açıklanmış olmasına ră̆men hem çok geniş hem de belirsizdir. Maddenin gerekçesinde geçen "Para, yarar veya vaat kabulü suretiyle bugün Türk askerinin Klbris'tan çekilmesi veya bu konuda Türkiye aleyhine bir çözüm yolunun kabulü için veya sırf Türkiye'ye zarar vermek maksadıyla, tarihsel gerçeklere aykırı olarak, Birinci Dünya Savaşı sonrasında Ermenilerin soykırıma uğradıklarının basın ve yayın yoluyla propagandasının yapılması gibi." ifadesi, bu maddenin kapsamının genişletilebileceğini göstermektedir. Burada Yeni Ceza Kanununu eleştirmenin madde kapsamında değerlendirilmeyeceğinin garantisi var mıdır? Fransız Parlamentosunda "Ermeni soykınm yapılmıştır." şeklinde bir kanun hazırlanmasını haklı olarak eleştiren Türk kanun koyucusunun "Ermeni soykırımı yoktur." şekline yönelik bu ifadeyi de kullanmaması gerekirdi. Bu madde çok ciddi sorunlara yol açabilecek ve düşünce ve ifade hürriyetini sınırlayan bir hüküm olduğu yolunda ciddi eleştirilerle karşılaşacaktır.

Türk hukukunun ve TCK uygulamasının 80 yıllık bir birikimi söz konusuyken Yeni Türk Ceza Kanunu'nun, bu birikim göz ardı edilerek hazırlanması, ceza kanunu sisteminin baştan sona değiştirilmesi, yerleşik kavram ve kurumların zedelenmesi ya da göz ardı edilmesi, ceza kanununun birçok hükmünün bir 
hukuk kitabında taşıması gereken ifadeleri içermesi, kanunun soyut ve genel ifadeler yerine yer yer kazuistik olması, gerekçe ile metnin tutarsız olması hukuk çevrelerinde "Hızlandırılmış Türk Ceza Kanunu" olarak ifade edildi. Türkiye'nin AB'ye üyelik hedefi de dikkate alındığında, Avrupa için henüz ortak bir ccza hukukundan söz etmek mümkün olmasa da Avrupa'nın belli bir hukuk ve insan haklan standardı olduğu gözetilerek, günün koşullarına göre TCK'nın dilinin sadeleştirilmesi, belli maddelerinin yenilenmesi ve belli maddelerin eklenmesi daha doğru olacaktı. Yeterince sağlıklı bir ortamda tartışılamayan, AB pazarlığı ve zina tartışması gibi bir kıskaca sokulan ve uzmanları hariç herkesin belirleyici olduğu Yeni Türk Ceza Kanunu çok yakında yürürlüğe girecek. 80 yıllık ceza hukuku birikimi ve Yargıtay uygulaması bir kenara bırakıldığından, belirsiz ve yoruma açık birçok hüküm içeren Yeni TCK'nın sisteminin oturması ve içtihatların oluşabilmesi için önümüzdeki yıllarda hakimlere, Yargıtay'a ve doktrine çok iş düşecektir. 